\title{
Parenting Styles as Correlates of Aggressive Behaviour Amongln-School Adolescent with Mild Intellectual Disability
}

\author{
Lokoyi O. L. O. \\ Department of General Studies, School of Education, Federal College of Education (Technical), Asaba, Delta State, Nigeria
}

\section{Email address:}

saintloveth@gmail.com

\section{To cite this article:}

Lokoyi O. L. O.. Parenting Styles as Correlates of Aggressive Behaviour Among In-School Adolescent with Mild Intellectual Disability. Psychology and Behavioral Sciences. Vol. 4, No. 3, 2015, pp. 94-100. doi: 10.11648/j.pbs.20150403.12

\begin{abstract}
Good and amiable parenting styles go a long way in moulding the child to face the exigencies of the future and protect the child from developing aggressive behaviours. In Asaba, adolescents with mild intellectual disabilities have exhibited aggressive behaviours in recent times. This paper therefore examined parenting styles as correlates of aggressive behaviours among in - school adolescents with mild intellectual disabilities. The study is a correlation study. Participants were purposely selected while the PSABIA questionnaire which contained information on personal data, parenting styles and aggressive behaviour respectively was used for data collection. The multiple regression was used to analyse data set at 0.05 level of significance. The study revealed that different parenting styles were associated with aggressive behavioural problems one way or the other. The study therefore recommended among others that dialogue, communication, explanation and the establishment of good and cordial relationship between parents and children should be encouraged.
\end{abstract}

Keywords: Parenting Style, Intellectual Disability, Aggressive Behaviour

\section{Introduction}

Habit and behaviour of a person is used in describing that person's character. However, there is a lot of difference between habit and behaviour. Behaviour refers to the actions of a living being or a system in response to the environment. It is the response of the system or the individual to various external impulsions (Wikipedia, 2012). Behavioural disorders can have negative influence on the academic performance of school children (Akpan, Ojinnaka \& Ekanem, 2010). Studies reported poor academic performance among children with behavioural disorder in the developed countries (Abolfotouh, 1997; Adams, Snowling Hennessy \& Kind, 1999).

Children with behavioural disorder have serious problems of social adjustment and are disruptive at home as well as in school and failed to make friends. They also had difficulties keeping notes to learn (Taylor, Everrit, Thorley, Schachar, Rutter \& Wieselberg, 1986). The home has a great influence on the students' psychological, emotional, social and economic state. The family is the primary agent of education in the child. Thus, the way the child lives, the food he/she eats and his/her life style is influenced by the family. The type of family system the child is exposed to could influence his behaviour (Akomolafe \& Olorunfemi-Olabisi, 2011). The family lays the psychosocial, moral and spiritual foundations in the overall development of the child. While the mother's significant role in this cannot be over-emphasized, studies on father-child relationship suggest that the presence of a father in the home influences significantly the development of a child (Agulanna, 1999; Eweniyi, 2002).

Alexander, Entwisle, and Bedinger (1994) averred that the parents' abilities to form accurate beliefs and expectations regarding their children's performance are essential in structuring the home and educational environment so that they can excel in post schooling endeavours. The belief that child-parent attachment plays an important role in social development occupies center stage in most contemporary theories of childhood socialization. The origins of this belief are easily traceable to Freud's emphasis on the significance of infant-mother attachment for virtually all aspects of subsequent personality development.

Good parenting and strong families can, in fact, help to protect children from many threats from the world outside and protect children from developing aggressive behaviours 
(Patten, 2000).Parenting style according to Darling and Steinberg (1993) is an attitude that is expressed toward the child across a wide-range of situations, whereas practices or behaviours are expressed toward the child's behaviuor in specific situations. The definition of parenting by Mize and Pettit cited in Hart, Nelson, Robinson, Olsen, and McNeillyChoque, (1998) is the "aggregates or constellations of behaviours that describe parent-child interactions over a wide range of situations and that are presumed to create a pervasive interactional climate.

\subsection{Parenting Styles}

Maccoby and Martin, (1983) re-conceptualized the parentchild relationship in two dimensions, consisting of degrees of parental responsiveness to psychosocial needs,based on the conception of four dimensions by Baumrind, (1967) which describes parent-child interaction, namely disciplinary strategies; warmth and nurturance; communication styles; and expectation of maturity and ability to self-control. On the basis of these dimensions, she identified three parenting styles: authoritative, authoritarian, and indulgent or permissive that influences the child's psychological wellbeing.

Maccoby and Martin (1983) assertion include warmth and support, and parental demands from their children (parental 'demandingness', i.e. how parents control their children's behaviour to achieve psychosocial objectives). Parental responsiveness is reported to predict social competence and psychosocial functioning, while parental 'demandingness' is associated with instrumental competence (academic performance and problem behaviour).

Authoritarian parenting is not only a restrictive and punitive style that insists on rigid adherence to rules, respect for work and effort, it also lacks warmth. Consequently, children from such homes acquire socially incompetent behaviours.Authoritative parenting allows extensive verbal give- and- take with their children. Thus, children from such homes are self-reliant, socially responsible and have socially competent behaviour.Permissive parents may be indifferent or indulgent. Permissive-indifferent parents exhibit inconsistency in their use of rules. They are generally uninvolved in the lives of their adolescent children.

\subsection{Literature Review}

Thornberry, Smith, Rivera, Huizinga and StouthamerLoeber (1999); Sanni, Nsisong, Abayomi, Felicia \& Leonard (2010) found that children who live in homes with only one parent or in which marital relationships have been disrupted by divorce or separation are more likely to display a range of behavioural problems including delinquencies than children who are from two parent families. Cashwell and Vacc (1996); Sanni, Nsisong, Abayomi, Felicia and Leonard, (2010) investigated the role of family cohesion and found that a cohesive family environment reduces the chances of aggressive behaviours.

Similarly, Shields and Clark (1995) Sanni, Nsisong,
Abayomi, Felicia \& Leonard, (2010) found out that low levels of adaptability in the family, results in higher levels of behavioural problem. It is apparent that there appears to be a relationship between family arrangements and delinquency in juvenile.

Russell, Hart, Robinson, and Olsen, (2003) concluded based on their study that low sociability combined with high authoritarian parenting was associated with less pro-social behaviour; however, interactions between shyness and parenting were not associated with pro-social or aggressive behaviour. Steinberg, Lamborn, Darling, Mounts, and Dornbusch (1994) showed that adolescent-reported authoritative parenting was associated with maintaining a higher level of social competence and adjustment across a two-year period of high school.

In contrast, authoritarian parenting was associated with increased internalized distress, while permissive parenting was associated with less distress and more externalizing problems. Parent-reported authoritative parenting was associated with less disruptive behavior in a sample of 3 to 6 year olds (Querido, Warner, \&Eyberg, 2002).Birch and Ladd, (1997); Esfandyari, Baharudin, and Nowzari, (2009) reported that parent-child relationships were found to have connection with child's school adjustment. The researchers found an association between higher self-esteem and high score in achievement test and that academic achievement is related to how children feel about themselves, which in turn is influenced by the relationships among family members, especially the parents.

Dornbusch, Ritter, Leiderman, Roberts, and Fraleigh, (1987) examined the relationship between authoritarian, permissive, and authoritative parenting styles and adolescent school performance. This investigation found that authoritarian and permissive parenting styles were negatively associated with higher grades, while the authoritative parenting style was positively associated with higher grades. Authoritative parenting may reduce the risks associated with various child characteristics and problem behaviours, negative parenting styles (i.e., authoritarian and permissive parenting) may heighten these risks for children with extreme temperaments (Propper and Moore 2006; Wood, McLeod, Sigman, Hwang\& Chu,. 2003).

While Avenevoli, Sessa, and Steinberg, (1999) concluded based on their findings that the combination of parenting style and family structure have different effects on children, it is noted that certain family structures or parenting styles do not have an impact on children all the same.

\subsection{Purpose of the Study}

1. Determine the relationship between parenting styles (authoritarian, authoritative and permissive) and aggressive behaviour among in-school adolescent with mild intellectual disability.

2. Determine the composite effect of parenting styles (authoritarian, authoritative and permissive) on aggressive behaviour among in-school adolescent with mild intellectual disability. 
3. Determine the relative contribution of each of the parenting styles (authoritarian, authoritative and permissive) on aggressive behaviour among in-school adolescent with mild intellectual disability.

\subsection{Research Question}

1. What is the relationship between parenting styles (authoritarian, authoritative and permissive) and aggressive behaviour among in-school adolescent with mild intellectual disability?

2. What is the composite effect of parenting styles (authoritarian, authoritative and permissive) on aggressive behaviour among in-school adolescent with mild intellectual disability?

3. What is the relative contribution of each of the parenting styles (authoritarian, authoritative and permissive) on aggressive behaviour among in-school adolescent with mild intellectual disability?

\section{Research Method}

\subsection{Research Design}

This study is a correlation study in which questionnaire was utilized to extract relevant information from participant. This study was geared towards identifying the relationship between parenting styles (authoritarian, authoritative and permissive) and aggressive behaviour among in-school adolescent with mild intellectual disability in Delta state. Correlation methods enables a researcher to obtain information from a representative sample of the population in order to describe the situation as they exit, and it also makes the evaluation of existing condition possible.

\subsection{Population}

The population in this study was parents of students with mild intellectual disability in public and private schools. The target population thus was in-school adolescents in Asaba, Delta state.

\subsection{Sample and Sampling Techniques}

The sample for this study was purposely selected from inschool adolescents with mild intellectual disability in Delta state in other to administer the research instruments to their parents.

\section{Instrumentation}

Questionnaires were administered on all participants. It was styled "Parenting Styles as Correlates of Aggressive Behaviour among In-school Adolescent" (PSABIA). It contained three sections (A, B and C). Section A sourced for information on personal data, while section $\mathrm{B}$ and $\mathrm{C}$ sourced for information on Parenting Style status and aggressive behaviour among In-school adolescent respectively.
Parenting Style: It assessed the level of a parent's or guardian's parenting style with respect to Baumrind's primary parenting styles typologies: authoritarian (high control, low warmth), permissive (low control, high warmth), and authoritative (high control, high warmth). The original PCPR consists of 62 items in which the parents or guardians indicate how often the stated behaviour is used when interacting with their children. For the purpose of the larger study, 10 items (3 authoritarian, 4 permissive, and 3 authoritative) with low factor loading scores $(<0.40)$ were removed from the copy of the PCPR received by the participants in this study, leaving 52 items in the assessment. Authoritarian items have a Cronbach alpha of .86, permissive items have a Cronbach alpha of .75 , and authoritative items have a Cronbach alpha of .91 (Robinson, Mandleco, Olsen, \& Hart, 1995).

Aggressive Behaviour Questionnaire (ABQ): The questionnaire also form part of the measuring instrument used in the study. It was formulated by the researcher based on observation of common social behaviour among pupils with intellectual disability. The aggressive behaviour questionnaire consists of 10 items.

The drafted copy of the instrument was subjected to cross examination and modification by expert in the field of special education. Copies of the questionnaire design by the researcher were field tested in a school for pupils/students with intellectual disabilities where participant with similar characteristics for the study are available for validation of the instrument. Reliability index was therefore obtained.

\subsection{Procedure for the Study}

The researcher with the services of four research assistants for the purpose of the research visited 6 schools selected for the studies to solicit the co-operation of respondents through the school head/administrator. The research assistants were educated on what their responsibility will be. Thereafter copies of the questionnaires were administered to all the participants selected as samples with the help of research assistants who are teachers in the schools selected for the study. Copies of the instrument were distributed and collected after a week interval.

\subsection{Method of Data Analysis}

Data was analysed using Multiple Regression Analysis statistical tools at 0.05 level of significance. Multiple regression was used to find out the combine and relative contribution of the independent variables on the dependent variables.

\section{Results}

Research Hypotheses One: What is the relationship between parenting styles (authoritarian, authoritative and permissive) and aggressive behaviour among in-school adolescent with mild intellectual disability? 
Table 1. Pearson Product Moment Correlation Coefficient of Relationship between the Independent and Dependent Variable

\begin{tabular}{llllc}
\hline & Authoritarian & Authoritarian & Authoritarian & Authoritarian \\
\hline $\begin{array}{l}\text { Authoritarian } \\
\text { Authoritative }\end{array}$ & 1 & $0.641^{* *}$ & -0.043 & $-0.042^{*}$ \\
Permissive & & 1 & $0.716^{* *}$ & $0.612^{* *}$ \\
Aggressiveness & & & 1 & $-0.029^{*}$ \\
\hline
\end{tabular}

*. Correlation is significant at the 0.01 level (2-tailed).

**. Correlation is significant at the 0.05 level (2-tailed).

Authoritarian, authoritative and permissive

Table 1 above shows that authoritative parenting styles had positive significant relationship on aggressive behaviour among in-school adolescent with mild intellectual disability $(\mathrm{r}=-0.12)$ at $\mathrm{p}<0.05$ confidence interval while authoritarian and permissive had significant relationship on aggressive behaviour $(r=0.612$ and 0.841$)$ respectively at $p<0.01$ confidence interval

Research Hypotheses Two: What is the composite effect of parenting styles (authoritarian, authoritative and permissive) on aggressive behaviour among in-school adolescent with mild intellectual disability? a. Authoritarian

b. Authoritative

c. Permissive

The data in table 2 above reveals that $(\mathrm{F}=23.437, \mathrm{p}<0.05)$. This indicated that there was significant joint effect of the independent variables parenting styles (authoritarian, authoritative and permissive) on aggressive behaviour among in-school adolescent. Null hypothesis is therefore rejected and alternate hypothesis is accepted. The adjusted $\mathrm{R}^{2}$ value of 0.549 shows that $55.4 \%$ of the variance in aggressive behaviour was due to collective impact of educational qualification, income and working hours.

Table 2. Summary of Regression for Composite Contributing Effect of the Independent Variables on the Dependent Variable.model summary

\begin{tabular}{lllll}
\hline model & R & R Square & adjusted R square & standard error of the estimate \\
\hline 1 & $0.768^{\text {a }}$ & 0.589 & 0.549 & 0.7058 \\
anova & Sum of squares & Df & Mean Square & F \\
Regression & 31.690 & 3 & 11.193 & $23.437^{*}$ \\
Residual & 26.211 & 47 & 0.498 & \\
Total & 57.901 & 50 & & \\
\hline
\end{tabular}

Research Hypotheses three: What is the relative authoritative and permissive) on aggressive behaviour among contribution of each of the parenting styles (authoritarian, in-school adolescent with mild intellectual disability?

Table 3. Relative Effect of Independent Variables on the Dependent Variables.

\begin{tabular}{lllll}
\hline \multirow{2}{*}{ coefficient } & \multicolumn{2}{c}{ unstandardized coefficient } & standardized coefficient & T \\
\cline { 2 - 4 } & B & std error & beta & 1.504 \\
\hline constant & 1.014 & 0.674 & & $-2.316^{*}$ \\
Authoritarian & -0.291 & 0.132 & 0.125 & 1.437 \\
Authoritative & 0.172 & 0.149 & 0.136 & $3.119^{*}$ \\
Permissive & 0.753 & 0.134 & \\
\hline
\end{tabular}

Predictors: (Constant), authoritarian, authoritative and permissive

Dependent Variable: Aggressiveness

Table 3 above shows the relative degree of association between authoritarian, authoritative and permissive and aggressive behaviour among In-school adolescent. They include authoritarian $(\beta=-0.224, \mathrm{t}=-2.316, \mathrm{p}<0.05)$, authoritative $(\beta=0.125, \mathrm{t}=1.437, \mathrm{p}<0.05)$ and permissive $(\beta=0.136, \mathrm{t}=3.119, \mathrm{p}=<0.05)$

\section{Summary of Findings}

The findings of the research are summarized below:

1. It was revealed based on the analysis of data that there was significant positive relationship between authoritative parenting style and aggressive behaviour among In-school adolescent

2. The study revealed that authoritarian and permissive parenting style had negative relationship with aggressive behaviour among in-school adolescent with mild intellectual disability

3. The study showed the independent variables (parenting styles) had combine effect on aggressive behaviour among in-school adolescent with mild intellectual disability.

4. Findings of the study revealed that permissive parenting style contributed most to aggressive behaviour among in-school adolescent with mild intellectual disability.

\section{Discussion of Findings}

Table 1 reveals that authoritative parenting style have positive significant relationship with aggressive behaviour 
among in school adolescent with mild intellectual disability while authoritarian and permissive parenting style had negative significant relationship.

This study is consistent with the report of Levy's study (1943; quoted in Shamlu, 1993)that revealed that applying both permissive and authoritarian parenting styles lead to the display of aggressive, delinquent and anti-social behaviors in children. The result is also in agreement with Anola (2000), that consistent positive encouragement in authoritative style may increase motivation of the children to make progress and achieve identity. Furthermore, Odubote (2008) reported that authoritarian parenting style is highly correlated with delinquency behavior, adding that the authoritative parenting style has been associated with positive outcomes. In contrast permissive and authoritarian parenting style has been associated with delinquency.

Table 2 result shows that there was significant composite effect of the independent variables, parenting styles (authoritarian, authoritative and permissive) on aggressive behaviour among in-school adolescent. The findings is consistent

Avenevoli, Sessa, and Steinberg, (1999) suggested from their findings that the combination of parenting style and family structure have different effects on children, and that certain family structures or parenting styles do not have an impact on children all the same. Pohl, Bender, and Lachmann (2005) found that women tend to show more empathy than men, and men tend to be more assertive than women. People may assume that that finding applies to all men and women and that there cannot be assertive women and empathetic men. Also the finding that mothers are perceived on average as spending more time taking care of their children than fathers even when working full time supports what we know about the second shift and men and women's perceived responsibility in and out of the home (Hochschild, 2003).

Table 3 result reveals the relative contribution of each of the parenting styles. The result is in agreement with report of Russell, Hart, Robinson, and Olsen, (2003) that low sociability combined with high authoritarian parenting was associated with less pro-social behaviour; however, interactions between shyness and parenting were not associated with pro-social or aggressive behavior. Steinberg, Lamborn, Darling, Mounts, and Dornbusch, (1994) found that adolescent-reported authoritative parenting was associated with maintaining a higher level of social competence and adjustment across a two-year period of high school. In contrast, authoritarian parenting was associated with increased internalized distress, while permissive parenting was associated with less distress and more externalizing problems. Parent-reported authoritative parenting was associated with less disruptive behaviour in a sample of 3 to 6 year olds (Querido, Warner, \& Eyberg, 2002).

\section{Conclusion}

Findings from this study reveal that different parenting style is associated with aggressive behavioral problems. Although, authoritative parenting style continues to influence children's development in positive ways beyond childhood and also adolescence, but conceptually, the authoritative style parents have both responsive and demanding dimensions. Their children have fewer behavioural problems and a high rate of academic achievement in school. Thus, with high demand and responsiveness between parent and child, there will be less internalizing and externalizing symptoms. In contrast, permissive parents are responsive but they are not demanding. So their children tend to get passive and be unresponsive in their interaction with others, become dependent and lack social responsibility. It is also assumed that the permissive parenting style will be associated positively with internalizing and externalizing behaviour in children. Also, authoritarian parents are only demanding but they are unresponsive. They utilize the punishment for their own children. Hence, being too strict in childhood may result in children's behaviour problems.

Thus, it is essential that family members are equipped with appropriate knowledge and skills so that they can provide better guidance for their children's positive development, especially socially acceptable behaviour. Parental demandness and responsiveness play crucial role in adequate parenting of children with mild intellectual disability. Adequate monitoring, control, supervision irrespective of the gender, school location and age are paramount factors in positive and effective child rearing. Adequate parental love, warmth, care, attention are factors for effective parenting.

\section{Limitation to the Study}

This study has some limitation:

1. The study is limited to in-school adolescent with mild intellectual disability in DeltaState, Nigeria because of the scope of the study.

2. The researcher also encountered problem with some respondent who were not interested in responding to the items.

\section{Recommendation}

Based on the findings of this study, the following recommendations are made.

1. Creation of a suitable environment for child rearing and provision of the child's need may prevent the development of aggressive behaviour among in-school adolescent with intellectual disability.

2. Dialogue, communication, explanations and establishment of good and cordial relationships between parents and their children should be encouraged as this could enhance positive and effective parenting.

3. Situation resulting from parental over reaction to issues, harsh environment and parental aggression should not be allowed to affect the children as this may make their children take to aggressive behaviour as a means of showing displeasure. 


\section{References}

[1] Abolfotouh M. 1997. Behavioural disorders among school boys in South Western Saudi Arabia. E Medit Health Journal.; 3:274-283.

[2] Adams J, Snowling M, Hennessy S, Kind P. 1999 Problems of behaviour, Reading and Arimethic, assessment of comorbidity using the strength and difficulties questionnaire. $\mathrm{Br} \mathrm{J} \mathrm{Ed}$ Psychology 69:571-585.

[3] Agulanna, G. G. 1999. Family structure and prevalence of behavioural problems among Nigerian adolescents. The Counsellor, 17(1), 154-1549.

[4] Alexander, K. L., Entwisle, D. R., \&Bedinger, S. D. 1994. When expectationswork: Race and socioeconomic differences in school performance. Social Psychology Quarterly, 57, 283 299.

[5] Akomolafe, M. J and Olorunfemi-Olabisi, F. A. 2011 Impact of Family Type on Secondary School Students' Academic Performance in Ondo State, Nigeria. European Journal of Educational Studies 3(3), 481 -487 Retrieved August, 2012 from

http://www.ozelacademy.com/\%285\%29ejes\%20156\%20Jude \%20gel.tar.\%2022\%20\%C3\%85_ubat\%202011\%20paid.pdf

[6] Akpan, M.U. Ojinnaka, N. C. and Ekanem, E. E. 2010. Academic Performance of school children with behavioural disorders in Uyo, Nigeria. Afr Health Science.2010 June; 10(2): 154-158 Retrieved February, 2012 from http://www.ncbi.nlm.nih.gov/pmc/articles/PMC2956301/\#R7

[7] Avenevoli, S., Sessa, F. M., \& Steinberg, L. 1999. Family structure, parenting practices, and adolescent adjustment: An ecological examination. In E. M. Hetherington (Ed.), Coping with divorce, single parenting, and remarriage (pp. 65 -90). Mahway, New Jersey: Lawrence Erlbaum Associates, Publishers.

[8] Baumrind, D. 1978. Parental disciplinary patterns and social competence in children. Youth \&Society, 9(3), 239-251.

[9] Birch, S. H., \& Ladd, G. W. 1997. The teacher - child relationship and children's early School adjustment. Journal of School Psychology, 35, 61 - 79.

[10] Darling, N., \& Steinberg, L. 1993.Parenting style as context: An integrative model. Psychological Bulletin, 113, 487496.doi:10.1037/0033-2909.113.3.487.

[11] Dornbusch, S. M., Ritter, P. L., Leiderman, P. H., Roberts, D. F., \&Fraleigh, M. J. 1987. The relation of parenting styles to adolescent school performance. Child Development, 58, 12441257.

[12] Esfandyari, B., Baharudin, R., \&Nowzari, L. 2009. Background of Inter-Parental Conflicts and Internalizing Behaviour Problems among Adolescents European Journal of Scientific Research Vol.37 No.4 pp.599-607. Retrieved August, 2012 fromhttp://www.eurojournals.com/ejsr.htm

[13] Hart, C. H., Nelson, D. A., Robinson, C. C., Olsen, S. F., \&McNeilly-Choque, M. K.1998. Overt and relational aggression in Russian nursery-school-age children: Parenting style and marital linkages. Developmental Psychology, 34, 687-697.
[14] Hochschild A, M. A. 2003. The second shift [e - book]. Available from: Family \& Society Studies Worldwide, Ipswich, MA.

[15] Maccoby E. E \& Martin J. A., 1983. Socialization in the context of the family: Parent-child interaction. In: Mussen PH, Hetherington EM, eds. Handbook of Child Psychology. Vol. 4.Socialization, Personality, and Social Development. 4th ed. New York: Wiley,1-101.

[16] McLoyd V.C. 1989. Socialization and development in a changing economy: The effects of paternal job and income loss on children. American Psychologist; 44:293-302.

[17] Odubote, B.A. (2008). Parenting style, race and delinquency: A comparative study of European American, African American and Nigerian families.(Doctoral dissertation, University of Minnesota). [Online] Available: http://proquest.umi.com

[18] Patten, P. 2000. The Parent-Child Relationship as Violence Prevention.Parent News [Online], 6(4).Retrieved August, 2012 from http://npin.org/pnews/2000/pnew700/feat700.html

[19] Pohl, R., Bender, M., \&Lachmann, G. 2005. Autobiographical Memory and Social Skills of Men and Women. Applied Cognitive Psychology, 19(6), 745 - 759.

[20] Propper, C., \& Moore, G. A. 2006. The influence of parenting on infant emotionality: A multi-level psychobiological perspective. Developmental Review, 26, 427-460. doi:10.1016/j.dr.2006.06.003.

[21] Querido, J. G., Warner, T. D., \&Eyberg, S. M. 2002. Parenting styles and child behaviour in African American families of preschool children. Journal of Clinical Child Psychology, 31, 272-277.

[22] Russell, A., Hart, C. H., Robinson, C. C., \& Olsen, S. F. 2003. Children's sociable and aggressive behaviour with peers: A comparison of the US and Australia, and contributions of temperament and parenting styles. International Journal of Behavioral Development, 27, 74-86. doi:10.1080/01650250244000038.

[23] Sanni B. S, Nsisong A. U, Abayomi A. O, Felicia N. M and Leonard N. E2010. Family Types and Juvenile Delinquency Issues among Secondary School Students in Akwalbom State, Nigeria: Counseling Implications J SocSci, 23(1): 21-28 Retrieved April, 2012 fromhttp://www.krepublishers.com/02Journals/JSS/JSS-23-0-000-10-Web/JSS-23-1-000-10-AbstPDF/JSS-23-1-021-10-954-Sanni-K-B/JSS-23-1-021-10-954Sanni-K-B-Tt.pdf

[24] Shamlu S (1993). Psychopathology (Roshd publications) Tehran.

[25] Shields, G, and Clark, R. D 1995. Family Correlates of Delinquency: Cohesion and Adaptability. Journal of Sociology and Social Welfare, 22(2): 93-106.

[26] Steinberg, L., Lamborn, S., Darling, N., Mounts, N., \&Dornbusch, S. 1994. Over-time changes in adjustment and competence among adolescents from authoritative, authoritarian, indulgent, and neglectful families. Child Development, 65, 754-770.doi:10.2307/1131416. 
[27] Thornberry, T. P., Smith, C. A., Rivera, C., Huizinga, D., and Stouthamer-Loeber, M. 1999. Family disruption and delinquency. Office of Juvenile Justice and Delinquency Prevention, U S Department of Justic, Washington, D C, (NCJRS \#178285), September.
[28] Taylor E, Everrit B, Thorley G, Schachar R, Rutter M \& Wieselberg, M 1986. Conduct disorder and hyperactivity: A cluster analytic approach to the identification of behavioural syndrome. Br J Psy.;149:768-777. 